\title{
The Analysis of Factors in Increasing Patient Satisfaction in Hospital
}

\author{
Endang Etty Merawati ${ }^{1}$, Derriawan Derriawan ${ }^{1}$, Edy Supriyadi $^{1 *}$
}

\author{
${ }^{1}$ Pancasila University, Post-Graduate School, Jakarta, 10320, Indonesia \\ Corresponding Author: Email: edyyadi2@univpancasila.ac.id
}

\begin{abstract}
Patient satisfaction is the main thing that must be fulfilled in conducting treatment at the hospital. Factors that affect the level of patient satisfaction include the availability of adequate infrastructure, facilities, and information technology, including the availability of space and supporting tools related to medical or information system services. In addition, the behavioral factors of medical and non-medical personnel also greatly determine the level of patient satisfaction, especially those who are currently consuming street drugs that need special attention from the hospital's management. The samples in this study are 116 respondents living in Depok. The statistical method used in this study is the Structural Equation Modeling (SEM). The results of the study are: (1) There is no relationship between hospital infrastructure and the quality of service; (2) There is a relationship between the behavior of hospital medical and non-medical officers and the quality of service; (3) There is a relationship between hospital information technology and facilities on the quality of service; and (4) Cost is not a driving factor in choosing the hospital's infrastructure to increase the quality of service.
\end{abstract} Keyword: Quality of Service, Infrastructure, Facilities, Employee Behavior

\section{INTRODUCTION}

\subsection{Background}

Health is the main thing for a person's life. With a healthy condition, a person will be able to carry out his / her activities comfortably and can produce optimal work productivity. Maintaining health is very necessary by paying attention to the fulfilled requirements that the body needs physically and spiritually. The failure to maintain our health often occurs so that the treatment is needed for the mind and body to recover.

Hospital is one of the largest health installations, whereas there are types of service that support public health such as medical services, hospital support. pharmacy, non-hospital support, nursing and midwifery, and inpatient care. Not all hospitals have high service quality, but there are also those whose service quality is still low.

The Depok area located in West Java, is one of the areas with the level of population development that has increased from year to year as shown in Table 1 below, which becomes the object of this research.

Table 1 The Population in Depok from 2015 to 2019

\begin{tabular}{|c|c|}
\hline Year & Population \\
\hline 2015 & $2,106,000$ \\
\hline 2016 & $2,179,815$ \\
\hline 2017 & $2,254,513$ \\
\hline 2018 & $2,330,333$ \\
\hline 2019 & $2,406,826$ \\
\hline
\end{tabular}

Source: Central Bureau of Statistics, Jakarta (2020)
The increasing population of Depok area and the increasingly advanced economic conditions have resulted in the increased public awareness on health. This has resulted in an increase in the number of visitors to hospitals so that the hospitals and clinics have to add their capacities to the existing facilities and improve the quality of services provided. This is done to make the patient handling process to run quickly and the patients can be well served and feel comfortable during the treatment. There are only 7 public hospitals and 16 private hospitals that can accommodate Depok residents regarding the medication purposes. The level of comfort provided by service providers greatly affects an individual's satisfaction and dissatisfaction toward the service process. Therefore, the process of health services provided by the hospital should be able to support the patient's physical healing. In addition, it should also be able to increase the patient's confidence to try fighting the disease he or she is suffering from. Furthermore, health services must be affordable to patients who are going to be hospitalized for treatment. In order to improve the services to patients, of course there are several factors that must be considered by the hospital including the infrastructure, facilities, and behavior of medical and non-medical personnel, which are supported by the ready-to-use information system. Realizing that many existing hospitals are engaged in the same field, the hospital must make new breakthroughs in order to improve quality and try to attract patients so that the Hospital will increasingly have a place in the hearts of the community. Hospital as a public healthservice institution requires the existence of an information system that is accurate and reliable, and sufficient enough to improve health services for patients and other related 
environments. Data management in health-service institutions is an important component in realizing the hospital information systems. The objectives of hospital information systems include the hospitals being able to obtain accurate and precise data according to hospital needs and speed-up services so that the services provided can be effective and efficient. In addition, the existence of a hospital information system can help make it easier to provide services, so it can save the human-resource energy.

\subsection{Problem Identification}

The results of interviews with several patients who were treated in a hospital in Depok area, there were still unsatisfactory services from the hospital, including the doctor's schedule that was not on-time, so it needed a long waiting-time, the facilities were still incomplete, both infrastructure in the form of parking area that is less extensive and the facilities such as medicines that are not available at the hospital's pharmacy unit. Besides, the fees charged for certain actions were less affordable by the community.

\subsection{Problem Statements}

From the background and problem identification sections, the following problems were formulated: 1) Is there any influence of infrastructure on the level of health-services quality at Depok Regional Hospital? 2) Is there any influence of facilities (including IT) on the level of healthservices quality at Depok Regional Hospital? 3) Is there any influence of the medical and non-medical personnel on the level of health-services quality at Depok Regional Hospital? And 4) Is there any influence of facilities (including IT), which is moderated by costs, on the level of health-services quality at Depok Regional Hospital?

\section{LITERATURE REVIEW}

\subsection{State-of-the-Art}

Defining and understanding patient satisfaction will help structure an evaluation process which will provide an organization with adequate measures of the variables that contribute to patient satisfaction. Most patients even if they are usually satisfied with the services, they may not be uniformly satisfied with all aspects of the care they receive. The management would need to be in a position to be constantly aware as to how much is enough to result in high patient satisfaction and to make them keep coming back [1]. Patient satisfaction is related to the extent to which general healthcare and condition-specific needs are met. Patient satisfaction is a multidimensional construct that includes the degree of patient's positive feeling on satisfaction, quality of service, interpersonal behavior, communication, financial aspects, time spent with physicians, nurses, administrative staff, pharmacy service, accessibility to health-care service, convenience, the availability of care, and conditions of facilities during their health-care services [2].

The quality of hospital services by medical personnel and non-medical personnel is very decisive for patients who are undergoing treatments. In this study, we wanted to know the factors that influence the quality of patient-care which in turn will increase patient satisfaction with the coverage of patients as respondents who have been treated for 6 months in the Depok area hospital. Based on previous research, what affects the quality of service consists of facilities, infrastructure, and the behavior of medical and non-medical personnel, as supported by [3] [4] [5] [6] [7] [8], which descriptively stated that health services will increase patient satisfaction.

The difference with previous research, is that this study analyzed the factors that affect the quality of patient-care as well as the effect of cost as a moderating variable that will encourage improving the quality of patient-care due to the availability of infrastructure.

\subsection{Costs}

The costs incurred by patients who are directly related to treatment by the hospital in this study, were described by [9] as follows:

1) Admin Fee; 2) Doctor Fee; 3) Laboratory Costs; 4) Cost of Stay; 5) Drug Costs; 6) Cheap Canteen; 7) Affordable Parking Fees; and 8) Cost of Action.

\subsection{The Quality of Service}

Quality is the overall characteristics of a product or service that affect its ability to satisfy the stated or implied needs, and quality must start from the customer needs and end in the customer perception [10]. This means that a good quality of image is not based on the point of view or perception of the service provider, but is based on the customer's point of view or perception. Customer perception of service quality is a comprehensive assessment of the excellence of a service.

The indicators used to measure the quality of hospital services in this study are as follows [11]:

1. Comfortable room arrangement

2. Patient complaints are responded to quickly via SIMRS

3. Providing services according to the schedule set by SIM-RS

4. Accurate action services by medical personnel

5. Providing friendly and good service during the SIMRS treatment

6. Providing services using the Hospital Information System which is fast and correct according to the procedure

7. The ability of the medical center gives confidence to recover quickly

8. The ability of medical and non-medical professionals to carry out their duties. 


\subsection{Health-Service Infrastructure and Facilities}

Health-service facilities and infrastructure can be defined as a collaborative process for the utilization of all health facilities and infrastructure effectively and efficiently to provide professional services in an effective and efficient health service process [12]. The completeness of good infrastructure is very important in creating customer satisfaction. Clow in [13] stated that the quality of service is more difficult to evaluate than the quality of goods.

In this study, health-service infrastructure and facilities are the means of supporting patient satisfaction. The supporting factors based on [14] include:

1. The availability of sufficient general practitioners

2. The availability of various specialists

3. The availability of competent nurses

4. The availability of administrative software in serving patients

5. The availability of Patient Registration Application for treatment

6. The availability of administrative software in serving patients

7. The availability of patient registration applications who will seek treatment

8. The availability of software applications in the Pharmacy Laboratory

9. The availability of competent pharmacists

10 . The availability of professional laboratory personnel

11 . The availability of experienced administrative staffs

12. The availability of cleaning service staffs who are diligent

Meanwhile, the facilities indicators used in this study consist of [14]:

1. The availability of clean toilet rooms

2. The availability of a clean canteen

3. The availability of a cheap and affordable canteen

4. The availability of a comfortable waiting room

5. The availability of comfortable children's play areas

6. The availability of a proper nursing room

7. The availability of complete pharmacy services

8. The availability of pharmacy services at affordable prices
9. The availability of complete Rontgen space

10. The availability of a comfortable registration room

11. The availability of complete and appropriate consultation rooms

12. The availability of a large administrative room

13. The availability of service space for action

14. The availability of comfortable breastfeeding room

15. No smoking-room available

16. The availability of large parking area

17. The availability of adequate inpatient rooms

18. The availability of patient-service software and serverroom

\subsection{The Behavior of Medical and Non-Medical Personnel}

Professional health-workers should always apply the ethics in most of their daily activities. Ethics, which are norms of behavior or commonly known as moral principles, should always be upheld in the social life of human groups. Ethics that apply in modern society today are applied ethics, which usually involves a profession, in which it talks about ethical questions from the individual involved. So, in each profession, an order has been formed which is called the code of ethics profession.

The behavior of medical and non-medical personnel variable has the indicators as follows [15]:

1. Arrangement of a comfortable room

2. Patient complaints are responded to quickly via SIMRS

3. Providing services according to the schedule set by SIM-RS

4. Accurate action services by medical personnel

5. Providing friendly and good service during the SIMRS treatment

6. Providing services using the Hospital Information System, which is fast and correct according to procedures

7. The capable medical center gives confidence to recover quickly

8. The ability of medical and non-medical professionals to carry out their duties.

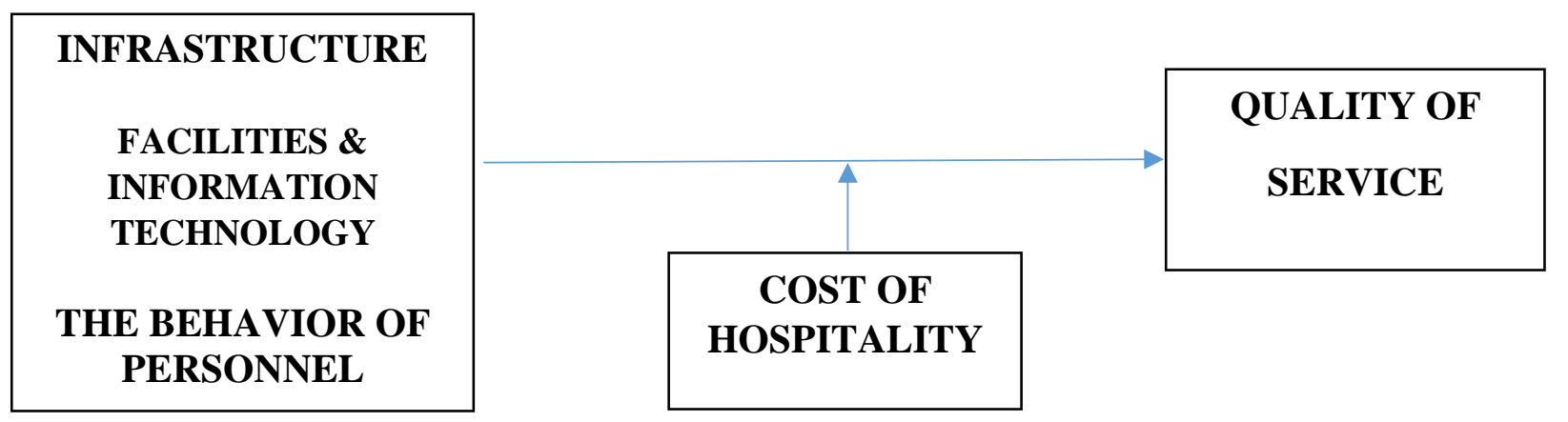

Figure 1 Theoretical Framework 


\subsection{Research Hypotheses}

$\mathrm{H}_{1}$ : Hospital Infrastructure affects the Quality of Service. $\mathrm{H}_{2}$ : Hospital Facilities and Information Technology affects the Quality of Service

$\mathrm{H}_{3}$ : The Behavior of Medical and Non-Medical Personnel affects the Quality of Service

$\mathrm{H}_{4}$ : Hospital Facilities and Information Technology affects the Quality of Service moderated by Costs.

\section{RESEARCH METHODS}

\subsection{Population and Sample}

\subsubsection{Population}

According to [16], population is a generalization of area consisting of objects or subjects that have certain quantities and characteristics that are determined by the researcher to be studied and then to draw conclusions. Based on the definition above, the population is a certain object or subject that is in an area and meets certain requirements related to the problem in the research. The population in this study were patients who had been hospitalized for the past 6 months at the Depok Regional Hospital.

\subsubsection{Samples}

Sample is part of the population whose characteristics can be investigated and are considered capable of representing the entire population. In this study, we used the purposivesampling technique. According to [24], purposive sampling is a sampling technique with special considerations so that it is appropriate to be sampled. This study took the respondents as a sample based on the patients who had been hospitalized for at least 3 days in the Depok area. According to Hair J.F, Anderson R.E, Tatham R.L, and Black W.C, in [17], it is suggested that the appropriate sample size for the
Structural Equation Modeling (SEM) analysis tool is between 100-200 respondents with the intention that it can be used in estimating the interpretations by SEM. In addition, the determination of minimum sample size for SEM according to [18] is dependable on the number of indicators multiplied by five to ten. In this study, a minimum of 126 questionnaires were distributed.

From the results of questionnaire distribution through Google Form, a list of questions was responded by only 116 respondents, which became the sample of this research.

\subsection{Data Collection Technique}

The questionnaire in this study was made based on the indicators of each research variable. The data source of the questionnaire is primary data that must be further processed by researchers. To obtain the primary data, such data was collected directly through distributing the questionnaires to people who have been hospitalized at the Depok Regional Hospital. Paying attention to the current situation of the development of Corona Virus Disease (Covid-19), whereas there is still an increase in the number of confirmed cases and to minimize the impact due to the spread of Covid -19 in the Depok area, data collection was carried out via electronic media using the Google Form which was distributed to respondents who have been hospitalized in the past 6 months at the Depok Regional Hospital.

\subsection{Research Variables}

The dependent variable in this study is the Quality of Service, while the independent variables consist of infrastructure, facilities and information technology, and the behavior of medical and non-medical personnel.

\subsection{Data Analysis}

Data analysis in this research used the Structural Equation Modelling (SEM).

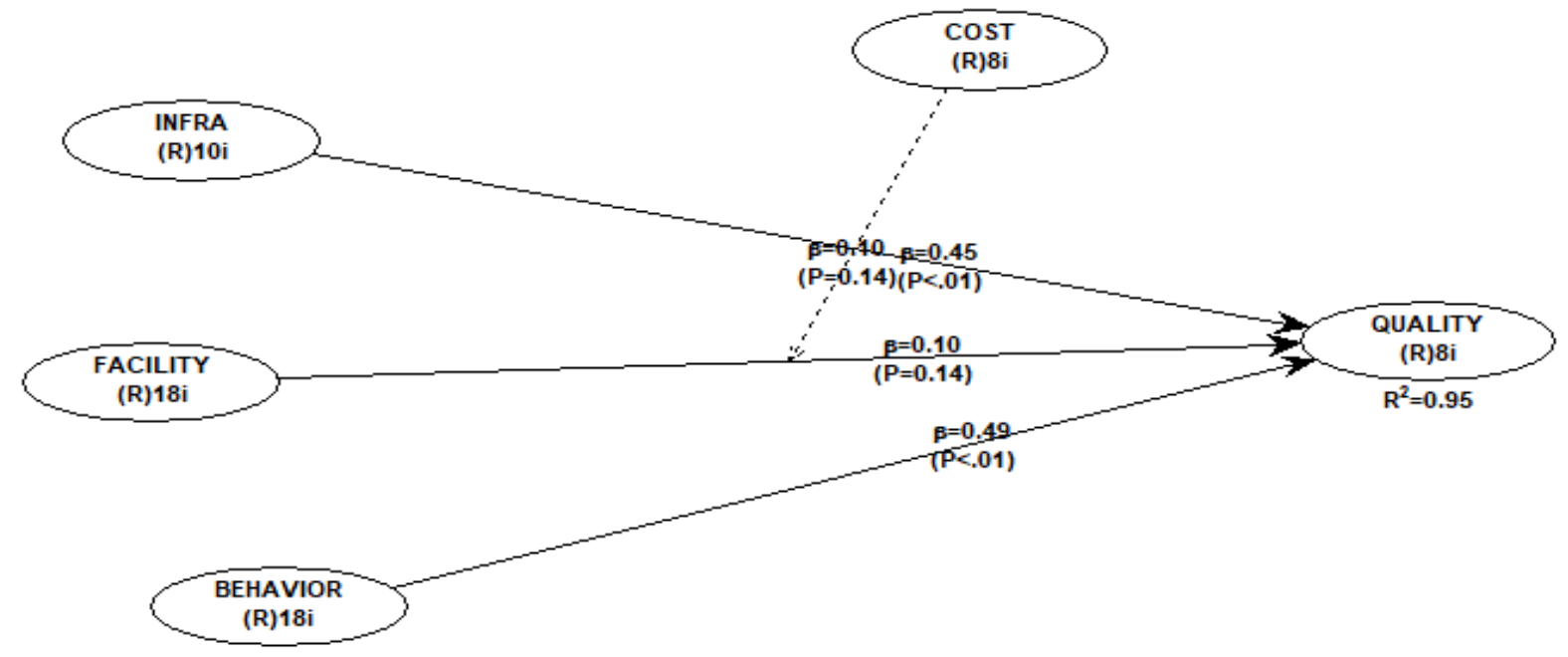

Figure 2 Statistical Diagram of Structural Equation Modeling 
The equation obtained from the converted flow-chart consists of the structural equation, of which the formula was developed as follow:

Structural Equation: QUALITY $=\beta_{1}$ INFRA $+\beta_{2}$ FACILITY $+\beta_{3}$ BEHAVIOR $+\beta_{4}$ FACILITY $*$ COST

\author{
QUALITY : The Quality of Service \\ INFRA : Infrastructure \\ FACILITY : Facilities and Information Technology \\ BEHAVIOR : Employees' Behavior
}

\section{RESULTS AND DISCUSSIONS}

\subsection{Data Analysis Results}

The coefficient of determination is $95 \%$, which means that $95 \%$ of the variation in patient satisfaction is influenced by the factors such as infrastructure, facilities (including IT), behavior, and costs, while the remaining $5 \%$ of the variation in patient satisfaction is influenced other variables not included in this study.

Table 2 The Results of Hypothesis Testing

\begin{tabular}{|c|c|c|c|}
\hline Relationship & $\begin{array}{c}\text { Path } \\
\text { Coefficient }\end{array}$ & $\begin{array}{c}\text { p- } \\
\text { Value }\end{array}$ & Decision \\
\hline $\begin{array}{c}\text { Infrastructure -> } \\
\text { Quality of Service }\end{array}$ & 0.100 & 0.135 & Not Supported \\
\hline $\begin{array}{c}\text { Facilities-Information } \\
\text { Technology -> } \\
\text { Quality of Service }\end{array}$ & 0.455 & 0.001 & Supported \\
\hline $\begin{array}{c}\text { Employees } \\
\text { Behavior -> } \\
\text { Quality of Service }\end{array}$ & 0.486 & 0.001 & Supported \\
\hline $\begin{array}{c}\text { Facilities * Cost -> } \\
\text { Quality of Service }\end{array}$ & 0.096 & 0.144 & Not Supported \\
\hline
\end{tabular}

Source: Data Analysis Results (2020)

Based on Table 2, the structural equation in this research could be developed as follow:

QUALITY $=0.1$ INFRA +0.455 FACILITY +0.486

BEHAVIOR + 0.096 FACILITY * COST

\subsection{Hospital Infrastructure Affects the Quality of Service}

The infrastructure provided by the hospital has no effect on the quality of service, because the patient's family will immediately bring their sick family members to the nearest hospital so that they can quickly get assistance for the treatment of diseases. Thus, they do not need to think long about which hospital to go, while considering the intended hospital infrastructure. In general, the family will take the patient to the nearest hospital from their residence location. On the other hand, the infrastructure has been adequate since several years ago and there are no visible changes in infrastructure so that the patients do not feel that the infrastructure can increase their satisfaction. [21] suggested that the role of management is important in improving the quality of patient care, having an impact on the external environment, hospital performance, networking, interaction with patients, and collaboration with other organizations.

\subsection{Hospital Facilities and Information Technology Affects the Quality of Service}

Facilities and information technology as service factors in the health-treatment process in hospitals have a significant effect on the quality of service. The results of this test concluded that the availability of facilities and technology information provided by the hospital can increase the quality of service. Even so, a health-service institution that has been equipped with adequate facilities such as the software application to serve all activities that can make the hospital operate more effectively and efficiently, but if it is not functioned as much as possible to serve the patients, such institution will not be able to provide satisfaction to the patients.

Complete and functional information facilities and technologies will significantly support the achievement of service-quality levels. In general, hospitals have been supported by adequate information technology and facilities, so it is necessary that the existing facilities can be used as much as possible to support the right services to patients, for example, x-rays, laboratory rooms, information technology software, and others.

[19] suggested that patient satisfaction is generally described as a description of the services received and the outcome of the treatment. Canceling or postponing diagnostic services reduces the level of patient satisfaction. These services include laboratory and radiology services.

[20] concluded that the necessary inputs from patients and attendants by pointing various drawbacks or deficiencies should always be taken care by the hospital administration unit, that will create a good result of improvement in the hospital services towards the satisfaction of patients.

\subsection{Medical and Non-Medical Hospital Personnel's Behavior Affects the Quality of Service}

The behavior of medical and non-medical personnel at the hospital has a significant effect on the quality of service, because patients and families, who already have experiences with such personnel with very-friendly services, will feel satisfied to undergo the medication process in the hospital. All hospital staffs realize that patient satisfaction is the main goal that must be achieved so that each individual participates actively in realizing the patients' satisfaction, for example, by increasing work discipline, providing more-friendly service, and others. The behavior of medical and non-medical officers will affect patient satisfaction, because one of the strategies to provide satisfaction to the patients is to display a sweet and polite behavior in serving them. 
[22] found that the degree of satisfaction was satisfactory with respect to the laboratory and diagnostic-care and parental-care services.

\subsection{Hospital Facilities and Information Technology Affects the Quality of Service, Moderated by Costs}

The series of facilities owned by the hospital in general do not make the patients pay attention to the condition of the hospital, the building, and the type of existing rooms. On contrast, if the patient comes from a family, of which the costs are not a problem, then the family can choose a hospital with good building, and of course it will be inclusive, so the patients can get satisfaction when undergoing the treatment. With the condition that the patient must immediately be taken to the hospital, the cost factor prepared by the patient and his / her family will not encourage them in choosing the target hospital. [23] told that the measurement of patient satisfaction and the capability to develop a satisfaction index for all units should become a component of comprehensive health-care quality assessment.

\section{CLOSING}

\subsection{Conclusion}

1. Hospital infrastructure has no effect on the quality of service.

2. Hospital facilities significantly affects the quality of service.

3. The behavior of medical and non-medical personnel in the hospital significantly affects the quality of service.

4. Cost is not a driving factor in choosing the hospital facilities which will affect the quality of service.

\subsection{Recommendations}

In order to support the efforts to improve service quality, there are several things that need to be fixed immediately, including:

1. All service personnel should be able to provide the information required by patients.

2. All service personnel must be able to provide morefriendly services to all patients without discrimination.

3. Instructions are given on the service-side of medical and non-medical officers who are good to be reminded at least once a month.

4. Hospital infrastructure needs to be developed in order to increase the satisfaction of patients when undergoing medical treatments.

\section{REFERENCES}

[1] Naidu. "Factors affecting patient satisfaction and healthcare quality", International Journal of Health
Care Quality Assurance, 22 (4), pp. 366-381, 2009.

[2] Vadhana Mao, “Assessment of patient satisfaction in an outpatient department of an autonomous hospital in Phnom Penh, Cambodia", Public Health Management, 2012.

[3] A. Gonul, Kant, Ozman, "Determinin Patient's Satisfaction with the Nursing Services Provided in an Oncology Clinic of Estern Turkey," International Journal of Caring Science, 10 (3), 2017.

[4] L. Alrubaiee, "The Mediating Effect of Patient Satisfaction of Heallth care Quaility -Patient Trust Relationship," International Journal of Marketing Studies, 3 (1), 2011.

[5] Agus Wahyu, “Analysis of Services Quality and Value Effect on Patient Satisfaction and Its Effect on Loyalty of Hospital Patients in Hospital and Children of Pucuk Permata Hati," Incontemporary Research Review, 2019.

[6] D. Georgiadou, Vasiliki A.; Maditinos, "Measuring the quality of health services provided at a Greek public hospital through patient satisfaction: Case study: the general hospital of Kavala," International Journal of Business, Economics, Science, and Applied Research, 10 (2), 2017.

[7] S. S. and A. Sayih2, “Assessment of Adult Patient Satisfaction and Associated Factors with Nursing Care Among Admitted Patient in Medical, Surgical, Obstetrics and Gynecology Ward in Mizan-Aman General Hospital, Bonga and Tepi Hospitals, Southwest Ethiopia 2016", JOJ Nurse Health Care, 8 (5), 2018.

[8] I. M. Sari1, S. W. Nasution2, E. Girsang2, and C. N. Ginting2, "Relationship of Nursing Service Quality to Patient Satisfaction Levels in Balimbingan Hospital 2018", International Journal of Resesearch Review, 6 (8), 2019.

[9] T. Herijanto, Ekonomi Kesehatan. Jakarta: PT. Rineka Cipta, 2014.

[10] P. Kotler, Manajemen Pemasaran. Jakarta: PT. Index, 2016.

[11] L. L. Zeithmal, Valarie A; Parasuraman, A; Berry, Delivering Quality Service: Balancing Customer Perceptions And Expectations. New York: The Free Press, 2016.

[12] A. Muhammad, Kesehatan Wanita, Gender dan Permasalahannya. Yogyakarta: Nuha Medika, 2010. 
[13] Febriani, Analisa Pengaruh Kualitas Pelayanan Terhadap Kepuasan Konsumen. 2012.

[14] Moenir, Manajemen Pelayanan Umum di Indonesia. Jakarta: Bumi Aksara, 2010.

[15] Kusumawati, "Professionalism and Professional Behavior Student Study Programme Medical Education Faculty of Medicine and Health Science University Muhammadiyah of Yogyakarta," 2011.

[16] Sugiyono, Metode Penelitian Kunatitatif Kualitatif dan R\&D. Bandung: Alfabeta, 2008.

[17] E. Supriyadi, SPSS AMOS. Jakarta: In-Media, 2015.

[18] Heirdz et. al, A Primer on Partial Least Square Structural Equation Modeling (SEM). 2017.

[19] J. Campbell, "Relationship of Interpersonal Behaviors and Health-Related Control Appraisals to Patient Satisfaction and Compliance in a University Health Center", Journal of American College Health, 55 (6), 2007.

[20] R. P. * Syed Shuja Qadri, P. , Mukhmohit Singh, SK Ahluwalia, Shveta Saini, and Garg, "An Assessment of Patients Satisfaction with Services Obtained From a Tertiary Care Hospital in Rural Haryana," International Journal of Collaborative Research on Internal Medicine \& Public Health, 4 (8), 2012.

[21] M. Zineldin, "The quality of health care and patient satisfaction. An exploratory investigation of the 5Qs model at some Egyptian and Jordanian medical clinics," International Journal of Health Care Quality Assurance. 19 (1), pp. 60-92, 2006.

[22] Faiza, Longbao Wei, Abid $\mathrm{H}$ and Muhammad Asif, "Patient Satisfaction with Health Care Services; An Application of Physician's Behavior as a Moderator", International Journal of Environmental Research and Public Health, 2019.

[23] P. Lochoro, "Measuring Patient Satisfaction in UCMB Health Institutions", Health Policy and Development, 2 (3), 2004. 